\title{
Innovation and Discovery
}

\author{
Vladimir Bacârea, Petruş Bacârea, Anca Bacârea
}

University of Medicine and Pharmacy, Tîrgu Mureș, Romania

\section{CORRESPONDENCE}

Vladimir Bacârea

Str. Gheorghe Marinescu nr. 38

540139 Tîrgu Mureș, Romania

Tel: +40 744645744

Fax: +40365801094

E-mail: bacarea@yahoo.com,

bacarea@gmail.com
Petrus Bacârea • Str Gheorghe Marinescu nr. 38 540139 Tîrgu Mureș, Romania. Tel: +40 265215551 Anca Bacârea • Str. Gheorghe Marinescu nr. 38 540139 Tîrgu Mures, Romania. Tel: +40 265215551
Innovation and discovery are the most important progress factors of human society. It is a paradox how actually the human natural tendency to ease work and enrich life makes society to progress, meaning that laziness and diversification of available goods are progress engines.

Since ancient times, innovative people have enjoyed the consideration of the community they were part of and have had material advantages in applying their own inventions. The only way to keep this advantage was to hold the secret on master level ("the handicraft must be stolen"), guild or secret society level (Masonry and Cathedrals constructions). On the other hand, society is also interested in promoting innovation, at least for the reason that it can benefit of new and improved products, but also of more efficient methods and technologies. This way, even from early stages, the necessity of regulations between innovation and society appeared, in order to defend the interests of each side and to stimulate innovation - a sort of "contract". In 1474, the Senate of the Republic of Venice introduced a law designed to promote innovation and protect the honor and interests of inventors. ${ }^{1}$ The main provisions of this law are: the exclusive right of the inventor or his agents to apply the invention, the novelty character in a region (in our case, Venice), the validity of 10 years, the obligation to achieve the object of the invention within one year from the registration date, and keeping the secret on the details. Galileo Galilei himself benefited from the provisions of this law, patenting his "water pump". ${ }^{2}$ Modern legislation extends the patent coverage area from a region to the entire world, increases the validity period to 20 years and, most importantly, declassifies invention details (these details are published in such a manner that allows any specialized person to reproduce the invention). ${ }^{2}$ European or worldwide databases containing the published patents have been created. Some of these databases are open-access, being a very valuable source of information. Also, they facilitate the review of invention novelty feature, allow companies to document before marketing a product to avoid violation of any active patent, and are a source of inspiration for researchers. ${ }^{3}$

A renowned example of indemnity for intellectual property infringement is the "instant camera" case. Kodak was sentenced to pay Polaroid the huge amount of 925 million euros as indemnification. 
The patent is some sort of contract between the inventor (applicant) and society, designed in such a manner to satisfy both parts and to stimulate innovation. The inventor has exclusivity in using the invention. This right can be transferred through sale (licensing), concession, or inheritance. No one has the right to commercially use an invention without the consent of the inventor. Society is interested in encouraging innovation because it brings new, better products, more efficient production methods and procedures. Small innovative companies are protected in competition with large firms. Invention details publication stimulates competition due to free access to information from the moment of patent application publication. This way, other people can bring improvements or can challenge the novelty feature. The possibility of transferring the commercial application right creates the premises of a beneficial specialization. For example, universities generate inventions, and companies apply them.

Patent protection works only when commercially applied, when seeking profit is desired. It is not applied for private or academic use. ${ }^{4}$

In the European Union, human or animal treatment methods by surgery or therapy, and also diagnostic methods cannot be patented, but the products used for such purposes, for example the medicines or instruments used, can be patented.

Dissemination of research results by publishing articles in specialized journals, unfortunately, often allows attempts of intellectual fraud by inserting unrealistic data that suits the promoted idea; substantial verification cannot be totally ensured by reviewers or, in journals that require a publication fee, the article is published upon the responsibility of the authors.

The way the system of intellectual property protection is organized and legislated at national, European, and worldwide level, stimulates organically scientific research and professional training by providing comprehensive information, review and validation of patent proposals and possibilities of moral and material reward for the applicants. That is why promoting the innovationpatenting system in universities represents a great opportunity.

\section{CONFLICT OF INTEREST}

Nothing to declare.

\section{REFERENCES}

1. Khan BZ. Looking Backward: Founding Choices in Innovation and Intellectual Property Protection. Available at: http://www.nber.org/ chapters/c11741.pdf.

2. Mumford L. Technics and Civilization. Available at: https://monoskop.org/ images/f/fa/Mumford_Lewis_Technics_and_Civilization.pdf

3. Patents And Innovation: Trends And Policy Challenges. Available at: https://www.oecd.org/sti/sci-tech/24508541.pdf

4. Giugni D, Giugni V. Intellectual Property: a powerful tool to develop biotech research. Microb Biotechnol. 2010;3:493-506. 